\title{
Effect of supplementary cementing materials on the concrete corrosion
}

\section{control}

\author{
R. Mejía de Gutiérrez*
}

\begin{abstract}
Failure of concrete after a period of years, less than the life expected for which it was designed, may be caused by the environment to which it has been exposed or by a variety of internal causes. The incorporation of supplementary materials has at the Portland cement the purpose of improving the concrete microstructure and also of influence the resistance of concrete to environmental attacks. Different mineral by-products as ground granulated blast furnace slag (GGBS), silica fume (SF), metakaolin (MK), fly ash (FA) and other products have been used as supplementary cementing materials. This paper is about the behavior of concrete in the presence of mineral additions. Compared to Portland cements, blended cements show lower heat of hydration, lower permeability, greater resistance to sulphates and sea water. These blended cements find the best application when requirements of durability are regarded as a priority specially on high performance concrete.
\end{abstract}

Keywords Supplementary cementing materials. Pozzolans. Slags. Blended cements. Durability.

\section{Efecto de materiales cementantes suplementarios en el control de la corrosión del concreto}

Resumen

Palabras clave
La falla del concreto en un tiempo inferior a la vida útil para la cual se diseñó puede ser consecuencia del medio ambiente al cual ha estado expuesto o de algunas otras causas de tipo interno. La incorporación de materiales suplementarios al cemento Portland tiene el propósito de mejorar la microestructura del concreto y también de contribuir a la resistencia del concreto a los ataques del medio ambiente. Diferentes minerales y subproductos tales como escorias granuladas de alto horno, humo de sílice, metacaolín, ceniza volante y otros productos han sido usados como materiales suplementarios cementantes. Este documento presenta el comportamiento del hormigón en presencia de diferentes adiciones. Los cementos adicionados, comparados con los cementos Portland muestran bajos calores de hidratación, baja permeabilidad, mayor resistencia a sulfatos y a agua de mar. Estos cementos adicionados encuentran un campo de aplicación importante cuando los requerimientos de durabilidad son prioritarios, especialmente en concretos de elevado desempeño.

Materiales cementantes suplementarios. Puzolanas. Escorias. Cementos adicionados. Durabilidad.

\section{INTRODUCTION}

Worldwide consumption of concrete today is approximately 9 billions tons per year and it is expected to grow during this century because concrete has become the major material for construction of dams, bridges, highways and other types of civil infrastructure ${ }^{[1]}$. This means that of more than 1.3 ton concrete are demanded per person in the world. In other words the production of concrete could be higher than the production of food.

The Earth Summit held in Rio of Janeiro in 1992, established that an economic development must be sustainable with respect to the earth's ecosystems. The industry of concrete attended this claim promptly because the great importance of its impact on the environment due to its high volume of production. After the Summit the concrete producers have been introducing new types of

(*) Grupo de Materiales Compuestos, Escuela de Ingeniería de Materiales, Universidad del Valle, AA. 25360, Cali, Colombia. 
cements based on the utilization of wastes and byproducts from the industries. The investigation and field experiences have been shown the benefits obtained when the cement are blended with wastes (supplementary materials) that have been proved do not be deleterious to the behavior of cement based products.

Today it is possible to taylor cements with specific properties, not only from the mechanical point of view but durability and chemical stability in high aggressive environments.

As some experts say we are in the new age where one of distinct signs is the availability of new types of cements which are energy-saving materials and a good business, but mainly they are good quality materials for building durable concrete structures. These new largely composite cements improve the properties of concrete and become potential materials for innovative applications ${ }^{[2]}$.

Portland cement is ordinarily used to produce common concrete but recently high performance concrete has gained importance because of concerns about durability of materials. The ACI Committee 201 defines durability of a hydraulic cement concrete as its "ability to resist weathering action, chemical attack, abrasion, or any other process of deterioration" "3]. The Committee states that "durable concrete will retain its original form, quality, and serviceability when exposed to its environment".

High compressive strength, constructability and durability are the basic conditions to be fit by a concrete of high performance. By using high performance concrete in high demanding applications, reduction in number and size of structural elements, with therefore important construction savings, are achieved. Here, the concept of durability has to be extended to the high strength concrete because of risks associated with the aggressive environments.

It is generally believed that concrete structures designed for a service life of more than 50 years would actually last much longer with nomaintenance. But the use of an inappropriate specification or the use of regular and improper materials or construction practice could be the cause of premature deterioration. The National Materials Advisory Board in USA published in 1987 a report where approximately 253,000 concrete bridge decks, some of them less than 20 years old presented many serious cases of deterioration $^{[4]}$. Other reports showed that numerous parking structures were deteriorated before their intended service life. Other concrete structures have suffered premature and serious deterioration such as tunnels, highways, marine piles. These effects and its repair and rehabilitation cause high costs. In the United States a estimate of the cost to rehabilitate deteriorated concrete structures are in the $\$ 100$ billion dollars range today ${ }^{[5]}$. The principal causes of deterioration in concrete structures could be attributed to the corrosion of reinforcing steel, the frost action, alkali-aggregate reaction, sulfate attack and the carbonation.

In 1993, ACI defined high performance concrete (HPC) as the concrete which meets special performance and durability requirements. That cannot always be achieved by using only conventional materials or procedures. The use of chemical and mineral admixtures is being recommended in this new material ${ }^{[3]}$.

The use of mineral admixtures or so called supplementary cementing materials offers new opportunities to concrete technology. With an adequate selection of the blending material and its chemical admixture, it is now possible to produce concrete for specialized applications, having ultra high strength, low permeability and high performance in several environments.

\section{SUPPLEMENTARY CEMENTING MATERIALS}

Different mineral by-products have been used as supplementary cementing materials; ground granulated blast furnace slag (GGBS), silica fume (SF), metakaolin (MK), fly ash (FA) and other products. The performance of these materials is closely related to the fundamental nature of the addition. Economic and environmental considerations have accelerated the use of these additions as concrete admixtures or as components of blended Portland cements. The selection of each supplementary material and its proportion in the concrete mixture is a function or the type and the characteristics of performance required and the $\operatorname{cost}^{[1]}$.

GGBS is non-metallic coproduct produced in the metallurgical industry, consisting essentially of silicates, aluminosilicates and calcium-alumina silicates. This material has latent hydraulic properties when is cooled and solidified by rapid water quenching to a glassy state from a molten at $1500{ }^{\circ} \mathrm{C}$ approximately. The glassy part of a slag is characterized as a large halo in X-ray diffraction patterns (Fig. 1). Its composition can vary as a 
Effect of supplementary cementing materials on the concrete corrosion control R.MEJÍA DE GUTIÉRREZ

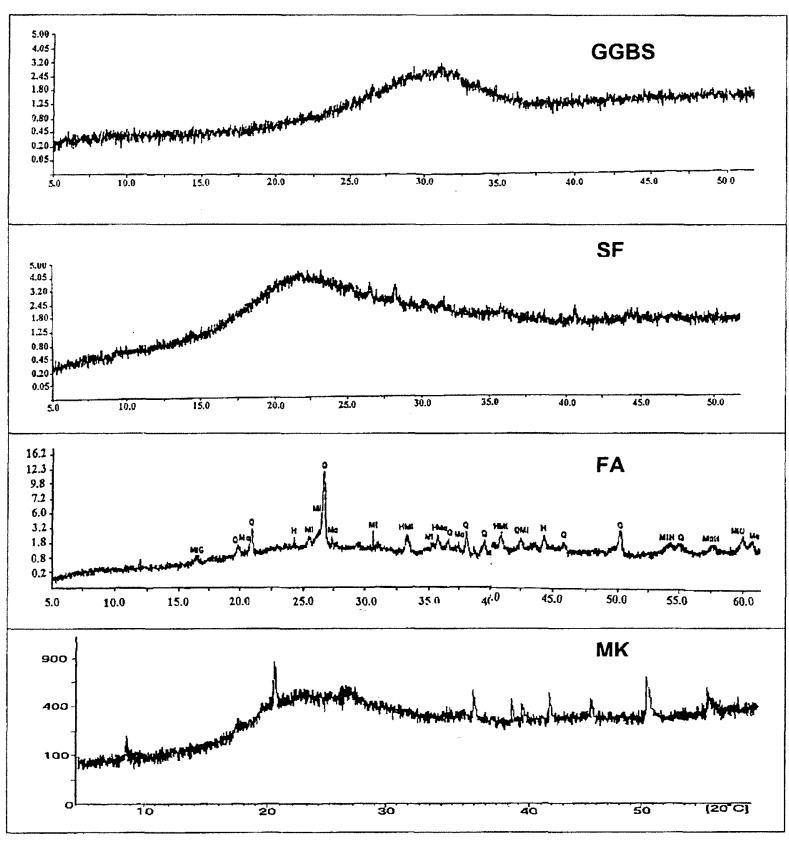

Figure 1. X-Ray pattern of different mineral additions ${ }^{[7]}$.

Figura 1. XRD de diferentes adiciones minerales ${ }^{[7]}$.

function of the metallurgical process. Some slags are cementitious whereas others are not. But the latter can be activated by the presence of Portland cement and alkaline substances ${ }^{[6]}$.

Silica fume is a by-product of the metallurgy of silicon alloys. This material has a very low density $\left(200-300 \mathrm{Kg} / \mathrm{m}^{3}\right)$ and a large BET surface area $\left(13000-30000 \mathrm{~m}^{2} / \mathrm{Kg}\right)$ and presents more than 95 $\%$ of silica content. The microsilica is considered a very active pozzolan.

Fly ashes are pozzolans produced in coal powder stations. They are mainly glassy. Their other phases are crystalline quartz, mullite, hematite and magnetite as is shown in figure 1. Figure 2 illustrates the shape of fly ash used in a collaborative research between Universidad del Valle (Colombia) and the Institute of Construction Sciences in Spain. The particles of fly ash are spherical and often hollow.

$\mathrm{MK}$ is a high reactive aluminosilicate pozzolan that it is produced by calcining pure kaolinite at $750{ }^{\circ} \mathrm{C}$. Its $\mathrm{X}$ ray diffraction pattern in figure 1 indicates a high amorphous character.

The specifications of these materials are categorized by chemical and physical properties for standard and optional requirements. Table I shows the specification for natural pozzolans, fly ashes and silica fume. The standard specification for GGBS for use in concrete and mortars is included in ASTM C989.

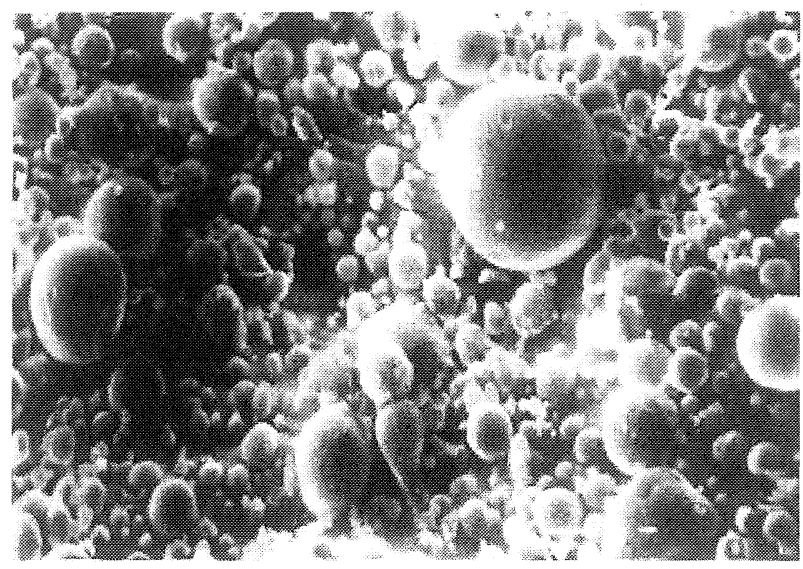

Figure 2. Micrograph of Fly Ash, SEM 2000X.

Figura 2. Micrografía de Ceniza Volante, SEM 2000X.

Table I. ASTM standard specification for pozzolans

Tabla I. Especificación estándar ASTM para puzolanas

\begin{tabular}{|c|c|c|c|c|}
\hline \multirow{2}{*}{$\begin{array}{l}\text { Type of Mineral } \\
\text { Additive }\end{array}$} & \multicolumn{3}{|c|}{ C-618 } & \multirow{2}{*}{$\begin{array}{r}\text { C-1240 } \\
\text { Silica } \\
\text { Fume }\end{array}$} \\
\hline & $\begin{array}{l}\text { Natu- } \\
\text { ral }\end{array}$ & $\begin{array}{l}\text { Fly Ash } F \\
\text { Type F }\end{array}$ & $\begin{array}{l}\text { Fly Ash } \\
\text { Type C }\end{array}$ & \\
\hline \multicolumn{5}{|c|}{ Chemical and phuysical requeriments } \\
\hline $\mathrm{SiO}_{2}+\mathrm{Fe}_{2} \mathrm{O}_{3}+\mathrm{Al}_{2} \mathrm{O}_{3}, \min , \%$ & 70.0 & 70.0 & 50.0 & $85+$ \\
\hline $\mathrm{SO}_{3}, \max , \%$ & 4.0 & 5.0 & 5.0 & - \\
\hline Moisture Content, $\max , \%$ & 3.0 & 3.0 & 3.0 & 3.0 \\
\hline Loss on ignition, $\max , \%$ & 10.0 & $6.0-12.0$ & 6.0 & 6.0 \\
\hline $\begin{array}{l}\text { Available alkalis, } \mathrm{Na}_{2} \mathrm{O}, \\
\max , \% \text { (optional) }\end{array}$ & 1.5 & 1.5 & 1.5 & 1.5 \\
\hline $\begin{array}{l}\text { Fineness, Retained on } \\
\text { № } 325 \text { sieve, max, } \%\end{array}$ & 34 & 34 & 34 & 10 \\
\hline $\begin{array}{l}\text { Strength activity index with } \\
\text { Portland Cement at } 28 \text { days, } \\
\text { min, percent of control }\end{array}$ & 75 & 75 & 75 & $85(7 d)$ \\
\hline $\begin{array}{l}\text { Water Requirement, max, } \\
\% \text { vs control }\end{array}$ & 115 & 105 & 105 & - \\
\hline
\end{tabular}

* Applicable only in concrete containing reactive aggregates $+\mathrm{As} \% \mathrm{SiO}_{2}$

The utilization of supplementary materials is raised in the cement and concrete industry. The interest of the producers has focused on the reduction of costs and secondarily in the benefits for obtaining more resistant cements and concretes. In general an active addition do increase the strength performance of cement. However by now, considerations about durability, volume stability and performance in aggressive environments have gained attention. 


\section{PROPERTIES OF BLENDED MATERIALS}

The small size and the spherical form of the particles of some fly ashes changes the flow behavior of the cement matrix, normally permits the water in the concrete to be reduced for a given workability (Table II). In this respect, this byproduct differs from others that usually increase the water requirements of concrete mixes. For example, the use of superplasticizer is mandatory in order to reduce the water demand of the mix due to the high specific area of the SF particles.

The chemical reaction of cement with water is exothermic. Most of the heat is liberated during the early stages of hydration. The rate of heat generation depends on the type of cement, the curing temperature and other variables. The temperature rise can be reduced by using fly ash as a portion of the cementing material, as is shown in table III. The effectivity of the fly ash incorporation compared with other additions is presented in figure 3. It is observed that fly ashes behavior is lesser than that of the metakaolinite. The incorporation of supplementary materials ordinarily renders minor quantities of hydration heat and its slower liberation diminishes the risk of thermal shrinkage and cracking of concrete. Because of these characteristics the products are being increasingly used in the production of mass concrete for dams, foundations, and underground linings.

The advantage of using $\mathrm{MK}$ in concretes is notorious after 1990 when some countries began its commercial production. Researchers have pointed out the increase in strength and reduction of permeability when MK is added to the cement ${ }^{[8-10]}$. Additionally, its white color is attractive in order to produce architectonic concrete.

Concrete containing a Fly ash may develop lower strength at 7 days of age or before but the continued pozzolanic activity of this product contributes to the increment of strength at later ages if the concrete is kept moist. The silica fume

Table II. \% of Water content with respect to the control mix without addition

Tabla II. \% de contenido de agua con respecto a la mezcla de control sin adición

\begin{tabular}{cccc}
\hline FA (30\%) & MK (30\%) & GGBS (70\%) & SF (15\%) \\
\hline 83.8 & 110 & 91.6 & 108 \\
\hline
\end{tabular}

Table III. Reduction percentage in the heat of hydration due to FA incorporation

Tabla III. Porcentaje de reducción en el calor de hidratación debido a la incorporación de Fly Ash

\begin{tabular}{ccccc}
\hline Curing Age, days & \multicolumn{5}{c}{ Addition Content, \% } \\
\cline { 2 - 5 } & 5 & 10 & 20 & 30 \\
\hline 1 & - & 68.8 & 85.6 & - \\
3 & 46.2 & 54.6 & 62.1 & - \\
7 & 21.5 & 49.2 & 54.7 & 74.6 \\
28 & 14.2 & 26.5 & 41.7 & 54.6 \\
\hline
\end{tabular}

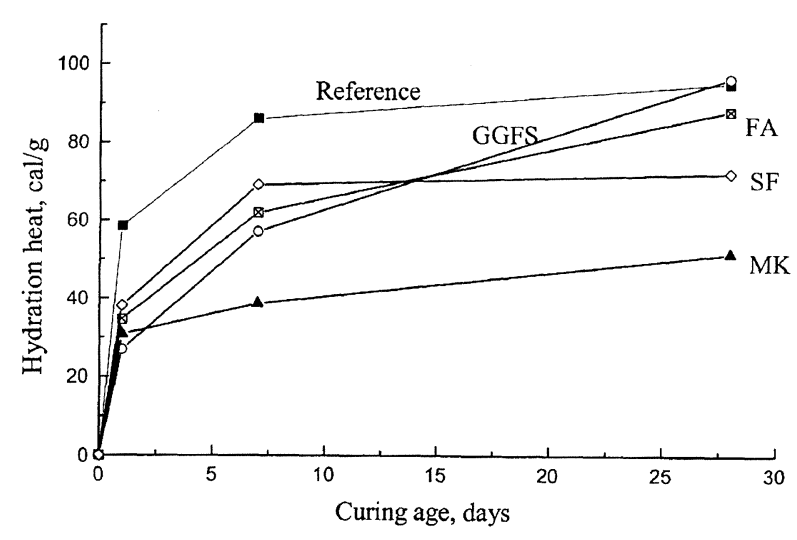

Figure 3. Hydration heat of blended cements.

Figura 3. Calor de hidratación de cementos adicionados.

contributes significantly to the compressive development of concrete but this property depends on various factors such as the percentage of SF (Fig. 4), curing conditions and age. The major contribution to the strength takes place at early ages.

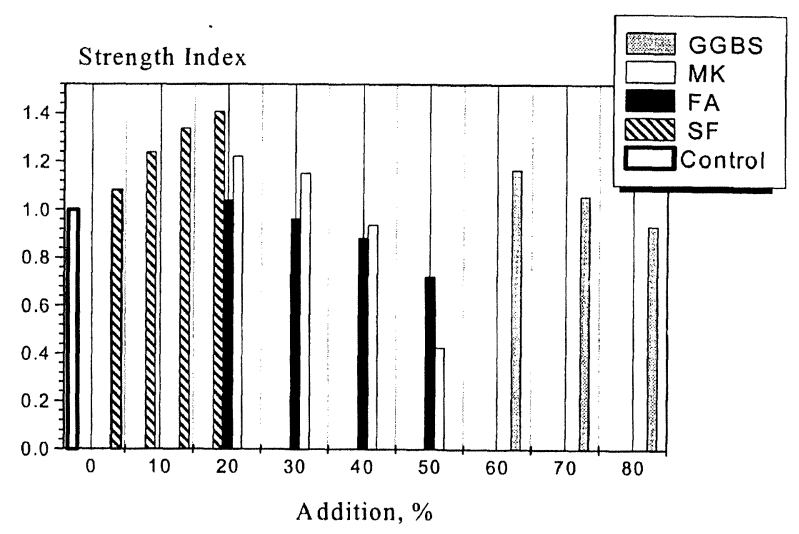

Figure 4. Strength index of blended concretes.

Figura 4. Índice de resistencia de concretos adicionados. 
The study of the Concrete durability takes into consideration the climate conditions, which influences the degree of microcracking and permeability of the concrete. Because of the number, distribution and size of pores the diffusion of aggressive substances is strongly influenced. Metha proposed a holistic model of deterioration of concrete ${ }^{[1]}$. This is shown in figure 5 . According to this model, a well constituted, properly consolidated and cured concrete remains watertight as long as the microcracks and pores in the interior do not form an interconnected network of pathways leading to the surface of concrete. With the environmental action, water, gases and ions play an active role in the damage of the concrete structure, if these capillary pathways and pores are present.

It is found that the pore structure of a cementitious matrix is changed through the reaction of the pozzolan and slag with the calcium hydroxide released during the Portland cement hydration as is shown in figure 6. The FA mortar presents a larger pore size than SF and GGBS concrete.

For structural applications, steel bars are used to reinforce the concrete. These bars are protected from corrosion because of the alkaline environment of the embedding concrete $(\mathrm{pH}$ around 13). A type of corrosion occurs when chloride ions diffuse in the concrete pores reaching the reinforced bars or when the $\mathrm{pH}$ values of concrete fall below 11 due to the $\mathrm{CO}_{2}$ diffusion and its reaction with $\mathrm{Ca}(\mathrm{OH})_{2}$ produced during the reaction of hydration of the cement, which is responsible for the hardening and strength development of cement and concrete. The former

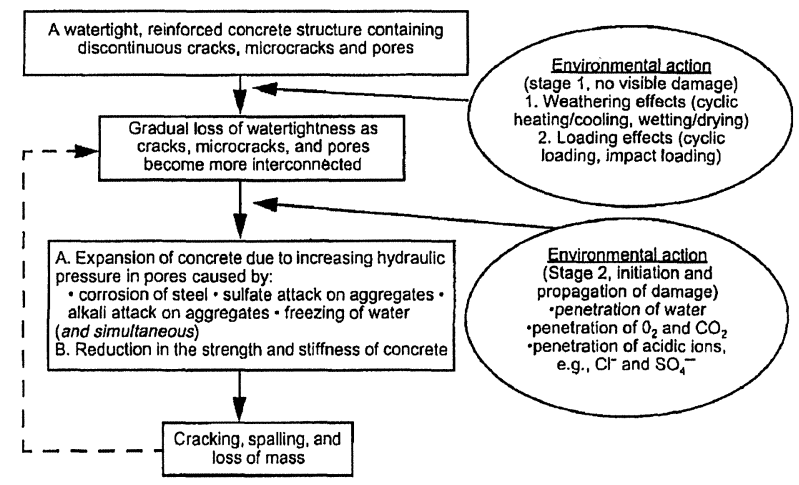

Figure 5. A holistic model of Concrete Deterioration proposed by Metha ${ }^{[1]}$.

Figura 5. Un modelo holístico del deterioro del concreto propuesto por Mehta ${ }^{[l]}$.
Pore Size Distribution, \%

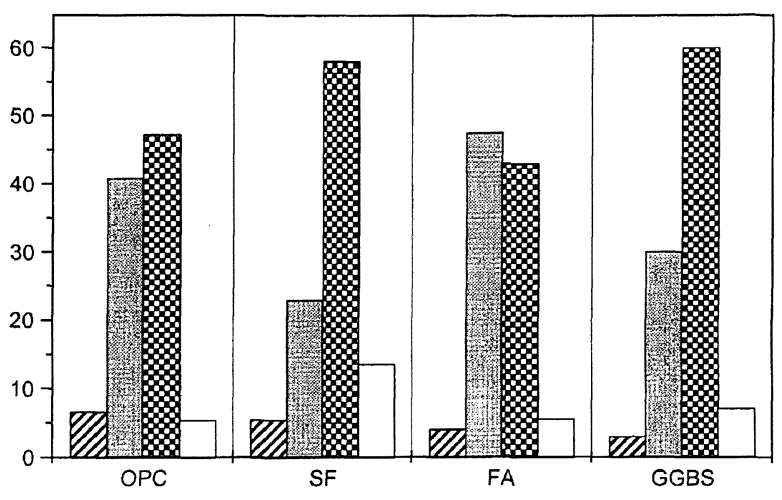

$\mathbb{Z}>1 \mu \mathrm{m} \quad 1-0.1 \mu \mathrm{m} \quad \otimes 0.1-0.01 \mu \mathrm{m} \quad \square 0.01-0.001 \mu \mathrm{m}$

Figure 6. Pore distribution in blended mortars.

Figura 6. Distribución de poros en morteros adicionados.

attack generally happens when the reinforced concrete is exposed to the marine environment in coastal areas. The latter happens especially in environments with high levels of $\mathrm{CO}_{2}$. Both of these attacks are favored by a greater porosity of concrete.

Chloride ingress into the concrete mass as ions, either by pure diffusion or by a combined mechanism of diffusion and water transportation in form of capillary suction and evaporation. Chlorides could locate in the inner pores of concrete, that could be totally or partially filled with water. Part of the Chloride ions are linked to cementitious compounds by chemical (reaction) and physical (adsorption) mechanisms. The probability of corrosion depends on the resistance of the concrete to Chloride penetration and to its binding capacity, because only the free-Chloride ions (boundless) will be aggressive to rebars.

The addition of SF significantly reduces the penetration of chloride ion into concrete due to the refined pore structure and increases the density of the matrix. In concrete with $15 \%$ of SF, the chloride penetration was found to be 370 coulombs at 56 curing days compared to 2980 coulombs for the reference concrete. Its diffusion coefficient is $83 \%$ lower than the reference ${ }^{[11]}$.

It should be noted that the diffusion coefficient of concretes with $70 \%$ of GGBS is $50 \%$ lower than that obtained in the same concrete but with $15 \%$ of SF. The value reported by an addition of 30 $\%$ of $\mathrm{MK}$ is similar to that given by GGBS. FA addition is less effective than the other additions.

In general the pozzolanic materials reduce the $\mathrm{Ca}(\mathrm{OH})_{2}$ content of the concrete, because they 
react with lime, so the carbonation in blended concrete is more probable. But the almost impermeable nature of the supplementary added concretes can impede the ingress of $\mathrm{CO}_{2}$ into the inner part of a concrete section. This factor depends on various factors, where the curing conditions are very important. Although some results presented in the technical literature are diverse, it seams that blended cements are very sensitive to inappropriate curing. In general, proper curing of concrete is essential to avoid excessive carbonation.

Sulfates react with the calcium hydroxide to form ettringite (sulfoaluminate of calcium), which causes expansion and cracking. In this case, due to the lesser calcium hydroxide content in the concrete added with SF or any other pozzolans, the chemical resistance is better than that of the reference concrete.

Several researchers have explored the possibility of using composite Portland cements, for example, silica fume in combination with fly ash. Here, the major purpose has been the use of the highly reactive pozzolan in order to compensate the slower strength development in fly ash concretes, although there are other possibilities.

Finally, it is important to emphasize some remarks about criteria for selection of mineral additions. The variables to be take into account to incorporate one or more supplementary materials consist of:

- Availability of the blending material.

- Energy saving of the process when addition is done.
- Appearance of the concrete.

- Cost reduction of the cement or concrete.

- Improvement mechanical properties of the concrete.

- Permeability reduction of concrete.

- Life service increase under selected exposure environments of the concrete.

In any case it is very important to cure appropriately in order to obtain a concrete with one or more of the desired properties.

\section{REFERENCES}

[1] K.P. METHA, Concr. Internat. July (1997) 27-33.

[2] M. Regourd, Mod. Concr. Mater. (1999) 87-100

[3] ACI, Manual of Concrete Practice, 1997.

[4] Report of National Materials Advisory Board, Publication $\mathrm{N}^{\circ}$ NMAB-437, Washington, 1987.

[5] ACBM, Cementing the Future 112 (2000).

[6] R. De Gutiérrez, S. Delvasto and R. Talero, J. Sol. Wast. Tech. Manag. 25 (1998) 113-116.

[7] R. De Gutiérrez, S. Delvasto and R. Talero, Proc. National Congress of Corrosion, Cartagena, 1999.

[8] R. De Gutiérrez, S. Delvasto and R. Talero, Mat. Constr. 50260 (2000) 5-13

[9] A. H. Asbridge, T. R. Jones and G. J. Osborne, Radical Concrete Technology, R.K. Dhir and P.C.Hewlet ed., London, 1996, pp. 13-24.

[10] J.M. Khatib and S. Wild, Cem. Concr. Res. 26 (1996) $1.545-1.553$.

[11] R. De Gutiérrez, S. Delvasto and R. Talero, J. Sol. Wast. Tech. Manag. 24 (1997) 74-78. 